\title{
In Vitro Study of Fermented Complete Feed by Using Sago Residues as Main Source Diet
}

\author{
Samadi $^{1)^{*}}$, Sitti Wajizah ${ }^{1)}$, Yunasri Usman ${ }^{1)}$ \\ Animal Husbandry Department, Agricultural Faculty, Syiah Kuala University, Banda Aceh, Indonesia \\ *Corresponding author email: samadi177@yahoo.de
}

\begin{abstract}
Recently, fermentation of low quality feed such as agro industry by products has been widely applied to produce enriched animal feed and improve animal productivity. The purpose of this study was to evaluate in vitro digestibility of fermented complete feed using agro-residues from sago starch processing industries as main source diet. Feed was formulated on the basis of $40 \%$ sago residue and mixed with other ingredients (rice brand, coconut meal, bread by product, soybean meal and soybean hulls) to fulfill the requirement of sheep with $16.10 \%$ of $\mathrm{CP}, 2.80 \mathrm{Mcal} \mathrm{ME} / \mathrm{kg}$ and TDN $60.88 \%$ based on calculation. Mineral and Urea were added in the complete feed to reach mineral and CP requirements of sheep. Complete feed formulation was fermented by using 3 commercial fermentation products (Saus Burger Pakan ${ }^{\circledR}$ (SBP), Probion ${ }^{\circledR}$ and EM $4^{\circledR}$ ) for 21 days. Total and types of microbes from commercial fermentation products utilized in this study were not determined. Parameters measured in this study were $\mathrm{pH}, \mathrm{NH}_{3}$, IVDMD (in vitro dry matter digestibility), IVOMD (in vitro organic matter digestibility) and VFA total. The model used for the statistical analysis was completely randomized design (CRD) with 4 treatments (control and 3 different commercial fermentation products) and 4 replications. Result indicated that administration of different commercial fermentation products into fermented complete feed based on sago residues significantly influenced $(P<0.05)$ on $\mathrm{pH}, \mathrm{NH} 3, \mathrm{VFA}$ total, IVDMD and IVOMD. Generally, commercial fermentation products mainly SBP produced better feed quality by improving the values of $\mathrm{pH}, \mathrm{NH} 3, \mathrm{VFA}$ total, IVDMD and IVOMD. However, types and total microorganisms needed to be determined prior to experiment.
\end{abstract}

Key Words: fermentation, sago waste, in vitro, complete feed

Abstrak. Akhir-akhir ini penggunaan bahan pakan berkualitas rendah yang berasal dari limbah industri pertanian telah diterapkan secara luas yang bertujuan untuk meningkatkan kualitas pakan dan produktivitas ternak. Tujuan dari penelitian ini adalah untuk mengevaluasi complete feed fermentasi berbahan dasar ampas sagu secara in vitro. Pakan diformulasikan dengan menggunakan $40 \%$ ampas sagu dan dicampur dengan bahan pakan lainnya (dedak, bungkil kelapa, sisa roti, bungkil kedelai dan kulit ari kedela) untuk memenuhi kebutuhan nutrisi domba (16,10\% of PK, 2,80 Mkal ME/kg and TDN 60,88\%). Mineral adan urea ditambah pada complete feed untuk memenuhi kebutuhan mineral dan protein dari ternak domba. Complete feed yang telah diformulasi difermentasi dengan menggunakan 3 produk fermentasi komersil (Saus Burger Pakan ${ }^{\circledR}$ (SBP), Probion $^{\circledR}$ and $\mathrm{EM}^{\circledR}{ }^{\circledR}$ ) selama 21 hari. Total dan jenis mikro organisme dalam produk fermentasi komersil tidak dihitung. Penelitian ini menggunakan rancangan acak lengkap yang terdiri dari 4 perlakuan dan 3 ulangan. Parameter yang dihitung dalam penelitian ini adalah $\mathrm{pH}, \mathrm{NH}_{3}$, total VFA dan kecernaan bahan kering dan kecernaan bahan organik. Hasil penelitian menunjukan bahwa fermentasi complete feed dengan menggunakan produk fermentasi komersial berpengaruh nyata $(\mathrm{P}<0.05)$ terhadap $\mathrm{pH}, \mathrm{NH}_{3}$, total VFA dan kecernaan bahan kering dan kecernaan bahan organik. Secara umum bahan produk fermentasi komersil terutama SBP dapat meningkatkan kualitas pakan dengan memperbaiki nilai $\mathrm{pH}, \mathrm{NH}_{3}$, total VFA dan kecernaan bahan kering dan kecernaan bahan organik. Namun penentuan jumlah dan jenis mikro organisme perlu dilakukan sebelum penelitian dilakukan.

Key Words: fermentasi, ampas sagu, in vitro, complete feed

\section{Introduction}

It is well known that feed plays an important factor in animal production (Samadi and Liebert, 2008; Samadi, 2012) and spends about
$70 \%$ of production cost in livestock enterprise. The use of low external input agricultural system coming from agro industry by products is able to reduce feed cost. However, feed from agro and industry by products contains lower 
nutritive values and digestibility. Several methods can be applied to improve nutrient content and digestibility of feed (Bisaria et al., 1997; Tang et al., 2008; Wanapat et al., 2009; Rahman et al., 2011; Shrivastava et al., 2011; Wajizah et al., 2015).

One of the agro industry by products that can be utilized as animal feed is agro-residues from sago starch processing industries which is abundant and readily available in Indonesia. Tampoebolon (2009) stated that sago waste contain $28.30 \%$ crude fiber and only $1.36 \%$ crude protein. According to Linggang et al. (2012) sago residues after the starch extraction process contain starch (58\%), cellulose (23\%), hemicellulose (9.2\%) and lignin (3.9\%). The high content of crude fiber and lignin results in slow and limited ruminal degradation of the carbohydrates in the rumen. In addition, the low content of nitrogen is the main deficiencies from agro residues causing the low value of residues as feed for ruminants (Van Soest, 2006).

In past years, many studies have been carried out to improve low quality residues as animal feed with various methods such as physics (Cristiyanto and Subrata, 2005; Viola et al., 2008; Samadi and Yu 2011; Samadi et al., 2013), chemistry (Bata, 2008) and biology (Pandey et al., 2000; Tang et al., 2008; Wajizah et al., 2015). Feed technology fermentation using microbial appears to be a practical and promising alternative to improve nutritional value of agro residues by processing these materials into animal feed and thus resulting in a value-added product. Research conducted by Zadrazil and Puniya (1995) by fermentation of sugarcane bagasse with white-rot fungi was able to improve the bagasse digestibility with all fractions and produce enriched animal feed. The purpose of this study was to evaluate in vitro digestibly of fermented complete feed by using agro-residues from sago starch processing industries as main source diet.

\section{Materials and Method}

\section{Sago residues and diet formulation}

Sago residue utilized in this study was collected from sago starch processing industry located in Krueng Mane, North Aceh and dried up to $10 \%$ of DM. Feed was formulated on the basis of $40 \%$ sago residue and mixed with other ingredients (rice brand, coconut meal, bread by product, soybean meal and soybean hulls) to fulfill the requirement of sheep (16.10\% of CP, 2.80 Mkal ME/kg and TDN 60.88\%) (SNI and NRC, 2007). Mineral and Urea were added in the complete feed to reach mineral and $\mathrm{CP}$ requirements of sheep. Complete feed formulation was fermented using 3 commercial fermentation products (Saus Burger Pakan ${ }^{\circledR}$ (SBP), Probion ${ }^{\circledR}$ and EM4 ${ }^{\circledR}$ ). These commercial fermentation products like SBP consists of various microorganisms such as cellulolytic, lactic acid, amylolytic microbes (Wulandari et al., 2014 ${ }^{\text {b }}$. Each treatment was added $0.3 \%$ of commercial fermentation product (except for control treatment) with $60 \%$ DM by adding water. Prior to fermentation, microorganisms from commercial products were activated in the $2 \%$ of molasses solution for 2 hours (Wulandari et al., 2014 ${ }^{\text {b) }}$. Samples were kept for anaerobe fermentation at room temperature for 21 days. The feed formulation for in vitro study is shown in Table 1.

\section{Chemical analysis}

Chemical analysis was conducted at Animal Nutrition Laboratory of Bogor Institute Agriculture and Animal Nutrition Laboratory of Syiah Kuala University, Banda Aceh. The method to measure in vitro analysis was based on Tilley dan Terry (1963) in which samples were incubated for 24 hours and continued for post rumen digestibility by adding of pepsin for the next 24 hours. Concentration of $\mathrm{pH}, \mathrm{N}-\mathrm{NH}_{3}$ 
Table 1. Composition of experimental diet based on sago residues as main ingredients (\% as fed)

\begin{tabular}{|c|c|c|c|c|}
\hline \multirow{2}{*}{ Ingredients } & \multicolumn{4}{|c|}{ Treatment* } \\
\hline & $\mathrm{F}_{0}$ (Control) & $F_{1}(S B P)$ & $\mathrm{F}_{2}$ (Probion) & $F_{3}(E M-4)$ \\
\hline Sago residue & 40 & 40 & 40 & 40 \\
\hline Rice brand & 18.5 & 18.2 & 18.2 & 18.2 \\
\hline Coconut meal & 18 & 18 & 18 & 18 \\
\hline Bread by product & 2.5 & 2.5 & 2.5 & 2.5 \\
\hline Soybean meal & 8 & 8 & 8 & 8 \\
\hline Soybean hulls & 8 & 8 & 8 & 8 \\
\hline Urea & 2 & 2 & 2 & 2 \\
\hline Molasses & 1.5 & 1.5 & 1.5 & 1.5 \\
\hline $\mathrm{NaCl}$ & 0.5 & 0.5 & 0.5 & 0.5 \\
\hline Mineral* & 1 & 1 & 1 & 1 \\
\hline Commercial Fermentation Product** & 0 & 0.3 & 0.3 & 0.3 \\
\hline TOTAL & 100 & 100 & 100 & 100 \\
\hline
\end{tabular}

and VFA total for in vitro analysis was determined according to Soejono (1996). Measurement of rumen $\mathrm{pH}$ was conducted at the end of every incubation period. Total VFA concentration was determined based on steam distillation and $\mathrm{N}-\mathrm{NH}_{3}$ concentration was measured by micro diffuse convey technique (General Laboratory Procedure, 1966).

\section{Statistical analysis}

Statistical analyses $(P \leq 0.05)$ used Statistical Software Package SPSS. The model used for the analysis was completely randomized design (CRD) with 4 treatments (control and 3 different commercial fermentation products) and 4 replications. The following is formula applied for statistical analysis: $Y_{i j}=\mu+T i+e i j$, where, Yij was an observation of the dependent variable $\mathrm{ij} ; \mu$ was the population mean for the variable; Ti was the effect of the fermentation, as a fixed effect, and eij was the random error associated with the observation ij. Differences between variables were compared by a oneway analysis of variance (ANOVA). Verification of variance homogeneity and identification of statistical significance was applied by Duncan multiple range test. Observations with $(P \leq 0.05)$ were considered statistically significant and trends were declared at $\mathrm{P} \leq 0.10$.

\section{Results and Discussion}

\section{$\mathrm{pH}$ value}

The $\mathrm{pH}$ value was considerably important to be measured due to rumen environmental condition. $\mathrm{pH}$ value can be used as indicator for feed degradation in which the range of $\mathrm{pH}$ value from 6.9-7.0 was optimum for cellulolytic microbes to degrade feed in rumen (Jean-Blain, 1991). If $\mathrm{pH}$ was lower than 6.2, cellulolytic microbes was disturbed and not able to grow optimally (Piwonka dan Firkins, 1996). The dynamic value of $\mathrm{pH}$ was an indication of feed level hydrolysis in which reducing of $\mathrm{pH}$ value had correlation with increasing of $\mathrm{N}$ microbes and increasing of total and partial VFA (Alltech, 2012). The result of $\mathrm{pH}$ value from this study is shown in the Figure 1.

The results of study showed that application of different commercial fermentation products for fermented complete feed had significant influence $(\mathrm{P}<0.05)$ on $\mathrm{pH}$ value of treatments. In this study, $\mathrm{pH}$ ranged from 6.79 to 7.0 and it was ideal condition for activity of cellulolytic microbes in rumen (Erdman, 1988). The value of $\mathrm{pH}$ from SBP was the lowest and 


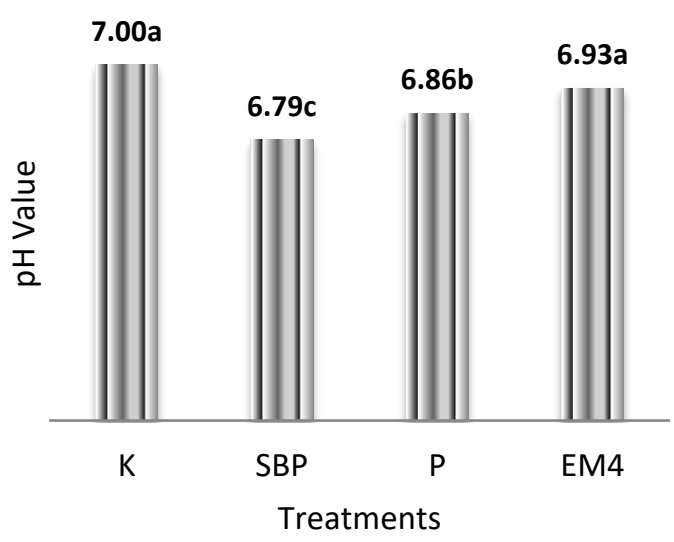

Figure 1. In vitro $\mathrm{pH}$ value of fermented complete feed based on sago residues as main ingredient feed with different commercial fermentation products. ( $\mathrm{K}$ (Control); SBP (Saus Burger Pakan); P (Probion); EM4 (Efektif Mikroorganisme-4)

followed by probion, EM4 and control with $6.79,6.86,6.93$ and 7.0 respectively. It was indicated that microbes from SBP and probion were effective to degrade structural carbohydrate from sago residues to be nonstructural carbohydrate and easily digested to produce VFA and other organic acids. Czerkawski (1998) stated that enzymes hydrolyzed non-structural carbohydrates first before structural carbohydrates.

Syahrir (2009) reported that $\mathrm{pH}$ rumen liquor reduced in the glucose, maltose and sucrose from 7.1 to 6.5 after a 4-hour fermentation. However, when tested in the same treatment using lactose, amylum and cellulose, $\mathrm{pH}$ decreased slowly from 7.1 to 6.9 after a 4-hour fermentation. Different results have been reported by Sangadji (2009) using sago waste fermented with fungi (Pleurotus ostreatus) to substitute natural grass in complete feed. In this study, $\mathrm{pH}$ was not significantly effective $(P>0.05)$ between treatments. It was probably due to high nutrient contents of diet between treatments in which the diet contained $40 \%$ of concentrate.

\section{$\mathrm{NH}_{3}$ concentration}

$\mathrm{NH}_{3}$ (ammonia) concentration in the rumen can be used as one of parameters to know the treatment effects on protein degradation. In the rumen, protein was degraded to peptide and amino acids and then degraded by microbes to ammonia. When protein was difficult to be degraded or in case of protein deficiency, ammonia concentration in the rumen was low and resulted in slow microbe growth (Wiryawan et al., 1999). $\mathrm{NH}_{3}$ concentration from this study is shown in the Figure 2.

The results from this study indicated that administration of different commercial fermentation products into fermented complete feed based on sago residues significantly influenced $(P<0.05)$ ammonia concentration after a 6-hour incubation. The highest concentration of $\mathrm{NH}_{3}$ was SPB, followed by probion, EM-4 and control with $32.47 \mathrm{mM}$, $30.59 \mathrm{mM}, 29.4 \mathrm{mM}$ and $24.42 \mathrm{mM}$ respectively. Mc. Donald et al., (2002) stated that optimum ammonia concentration for microbe protein synthesis in the rumen liquor was 5-17.65 $\mathrm{mM}$. $\mathrm{NH}_{3}$ concentration was high in all treatments, because ammonia at in vitro test was only utilized by microbes and not absorbed by rumen wall and excreted by urine. Therefore, ammonia was accumulated during in vitro test. In accordance with Hilakore (2008), fermentation putak with Aspergillus niger and Trichoderma reseei had 19, 09 mM ammonia concentration.

Previous experiment reported by Thalib et al. (2001) probion produced lower ammonium compared to probiotics contain cellulolytic bacteria like SBP. Increase of ammonia concentration by administration SBP, probion and EM-4 was as indication of the high soluble protein and enzyme degraded activities, proteololytic enzymes, from probiotic in degradation of protein (Dutta et al., 2001). In addition, increase of ammonia concentration was probably due to high ferment ability of fermented complete feed based on sago residues as a point of protein evaluation in ruminant animals. 


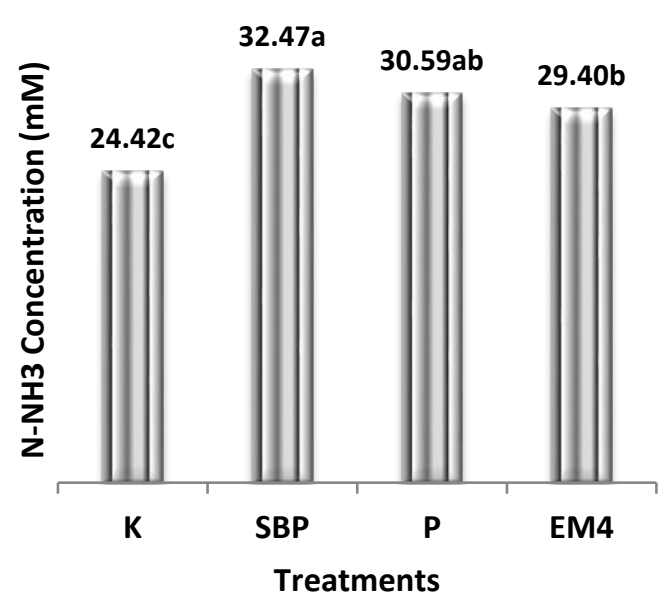

Figure 2. $\mathrm{NH}_{3}$ concentration of fermented complete feed based on sago residues as main ingredient feed with different commercial fermentation products. ( $\mathrm{K}$ (Control); SBP (Saus Burger Pakan); P (Probion); EM4

(Efektif Mikroorganisme-4).

However, lower ammoniac concentration in rumen reflected a good fermentation process and ammonia was able to be optimally utilized for animal productivity. Rumen microbes can use NPN such as urea and ammonia to formulate protein (Krause, 2001). Protein is considered a very important nutrition or growth and rumen microorganism to digest cellulose and as protein source for animals (Mc Donald et al., 2002). Low ammoniac concentration was indicated as either low degradation of protein or low protein concentration in diet. The last two reasons were assumed as low ammoniac content in rumen liquor, followed by low VFA concentration and digestibility (Syahrir, 2009).

\section{VFA concentration}

Carbohydrate digestibility in rumen produces VFA as main product and be used as main carbon bone for rumen bacteria and also energy for ruminant animals (Russell dan Wallace, 1997). VFA concentration is one or the indicators to measure fermentable feed with closely related to rumen microbe population. The amount of VFA production was affected by digestibility and fermented feed quality (Baldwin, 1995). VFA concentration from this study is shown in the Figure 3.

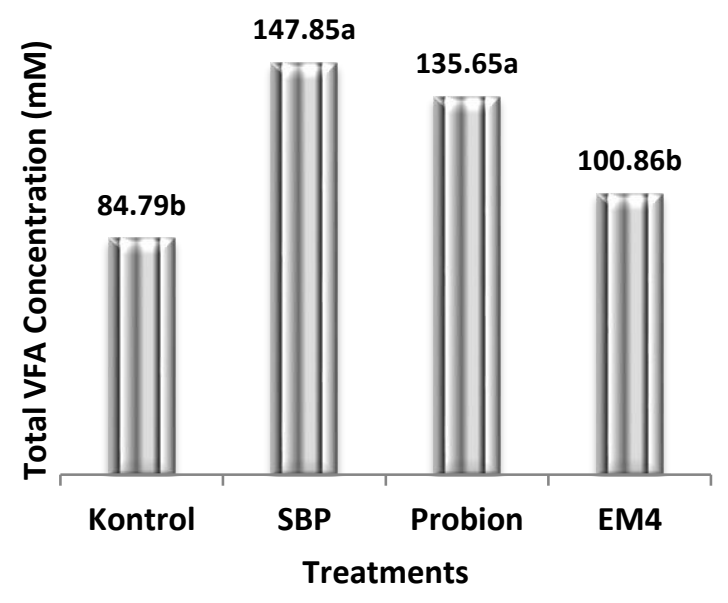

Figure 3. VFA concentration of fermented complete feed based on sago residues as main ingredient feed with different commercial fermentation products. ( $\mathrm{K}$ (Control); SBP (Saus Burger Pakan); P (Probion); EM4 (Efektif Mikroorganisme-4).

The results from this study shown that administration of different commercial fermentation products into fermented complete feed based on sago residues significantly influenced $(P<0,05)$ on total VFA concentration after a- 6 hour incubation. The highest total VFA was SBP and probion, 147.85 $\mathrm{mM}, 135.65 \mathrm{mM}$, respectively. But VFA total for control and EM-4 were not significantly different $(P>0,05)$. Concentration of VFA total in this study was sufficient for rumen microbe growth since more than normal condition as stated by Waldron et al. (2002) with the number of 60-120 mM. Application of probiotic was able to influence rumen ecosystem such as $\mathrm{pH}$, fermentation products such as VFA and NH3. Generally, probiotic improves VFA total production (Oeztuerk et al., 2005) as reported by Dawson dan Newman (1988) in vitro experiment.

Widyastuti (2008) stated that feeding animal with fermented feed offers chance for microorganisms to grow including LAB. The results from several in vivo studies with cattle fed on elephant grass silage with or without bacteria as inoculum showed differences on feed intake, bacteria population in rumen and 
VFA concentration. However, feed intake of cattle treated with bacteria inoculum consumed lower silage but total rumen bacteria, cellulolytic bacteria and propionate: acetate ratio were improved. It means that the use of energy was more efficient.

In this study, improvement of VFA total was linier with urea concentration for all treatments. VFA production was highest at SBP supported by ammonia availability and it is indicated that improvement of complete feed quality based on sago residues was able to optimize rumen fermentation. With ammonia, VFA play very important factors for optimum microbe growth and main source to perform microbe protein to be used for animals growth. Most of rumen microbes utilize ammonium for proliferation microba mainly for protein synthesis. Meanwhile, carbohydrate was hydrolyzed to be VFA as energy source (Suryahadi dan Amrullah, 1989).

IVDMD (in vitro dry matter digestibility) and IVOMD (in vitro organic matter digestibility)
Feed digestibility is defined as feed not excreted in feces and assumed to be absorbed by animals. Digestibility can be measured by in vitro technique presented in dry matter (Mc. Donald et al., 2002; Perry et al., 2003). Nutrient digestibility is one of indications to measure feed quality since it reflected the availability of nutrient for animals. Level of feed digestibility in rumen was affected by feed chemical composition mainly the content of protein and crude fiber, rumen fermentation condition including $\mathrm{pH}$, ammonia concentration and VFA supported digestibility during fermentation. Increase of feed digestibility resulted in higher VFA concentration as indication of improving animal productivity in which VFA is sources of energy for animals (Syahrir, 2009). The amount of VFA production was affected by digestibility and fermented feed quality (Baldwin, 1995). Figure 4 is shown IVDMD and IVDOM of fermented complete feed based on sago residues as main ingredient feed with different commercial fermentation products.

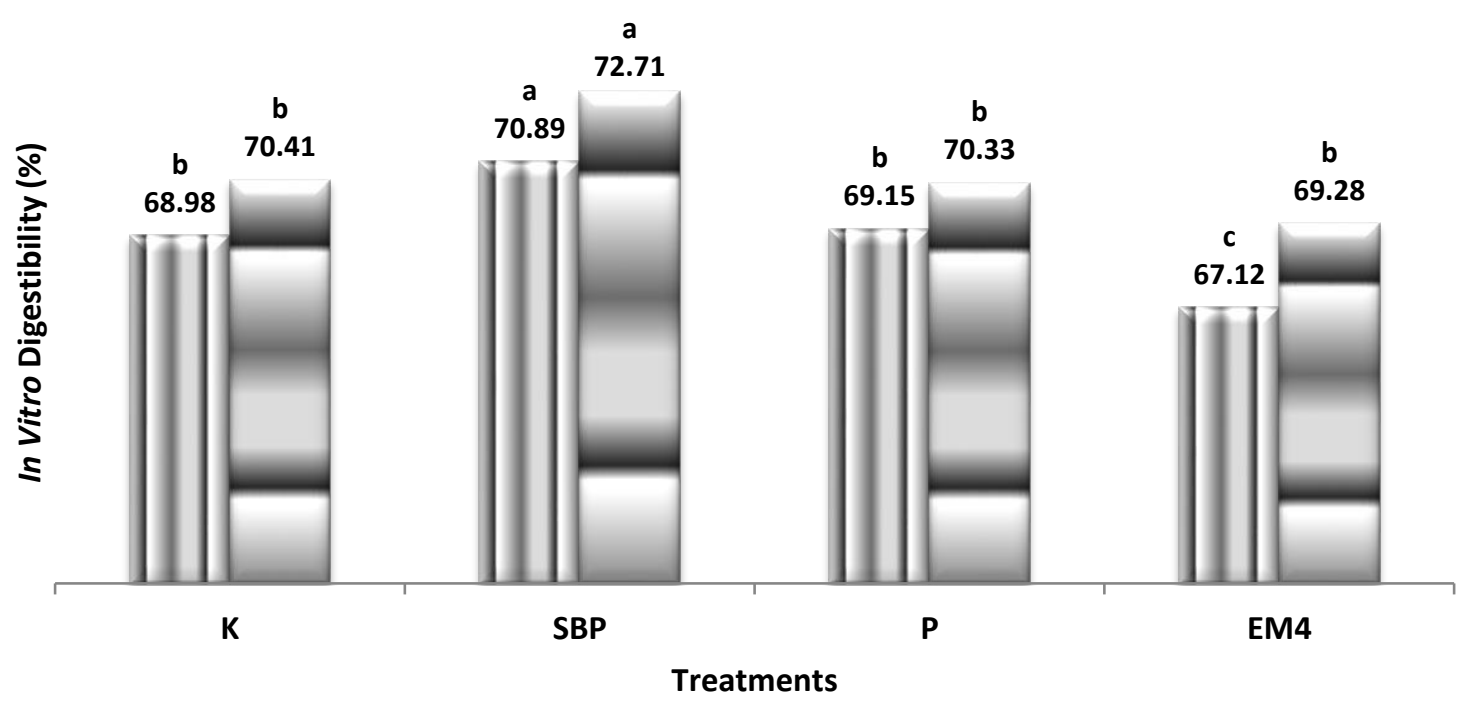

Wry Matter Organic Matter

Figure 4. IVDMD and IVDOD of fermented complete feed based on sago residues as main ingredient feed with different commercial fermentation products. (K (Control); SBP (Saus Burger Pakan); P (Probion); EM4 (Efektif Mikroorganisme-4). 
The results of this study showed that administration of different commercial fermentation products into fermented complete feed based on sago residues significantly influenced $(P<0.05)$ on the percentage of IVDMD and IVDOD. SBP is the highest of all treatments with $70.89 \%$ and 72.71\% IVDMD and IVDOD, respectively. Meanwhile, three other treatments were not significantly different $(P>0.05)$ on the percentage of IVDMD and IVDOD as shown in Figure 4.

The highest percentage of IVDMD and IVDOD from SBP because the inoculum of SBP consists of mixture of BAL, bacteria cellulolytic and amylotytic which has a role in reducing of $\mathrm{pH}$ and decreased crude fiber from cellulolytic bacteria (Wulandari et al., 2014 ${ }^{\mathrm{a}}$ ). In the ruminant diet, probiotic is able to increase total nitrogen enter to intestine and improved the ruminant ability to degrade cellulose and hemicellulose (Yoon and Stern, 1995). Improving in vitro digestibility was due to cellulolytic enzyme produced during fermentation process. Cellulolytic enzyme is complex enzyme gradually cutting at the $\beta-1,4$ glycosidic bond. This enzyme was able to cut cellulose chain to be cellebiose and finally produced glucose (Lin et al., 2012). Wulandari et al. $\left(2014^{\text {b }}\right)$ reported that even though there did not improve IVDMD and IVDOD from treatments, fermented complete feed based on cacao pod increased $(P<0.05)$ crude fiber digestibility. Crude fiber can influence total digestibility since crude fiber is one of the organic components which is difficult to be digested.

In addition, Wina (2005) reported that replacement of concentrate from fermented products resulted in increasing of total feed intake, dry matter digestibility, nitrogen retention and intake $\mathrm{N}$-microbes. Mechanism of digestible improvement from fermented feed was due to fermentation products that can be used by rumen microbes for growing and improve rumen to digest feed. In accordance with the research conducted by Hilakore (2008) feeding fermented putak $20 \%$ into concentrated improved dry matter digestibility and continued to increase up to $40 \%$ fermented putak in concentrate. It was concluded that fermented putak improved diet for animal growth. DMD was closely correlated with OMD because organic matter is the highest composition in dry matter. Decreasing of DMD results in reducing of DOM (Parakkasi, 1999).

\section{Conclusions}

In conclusion, administration of different commercial fermentation products into fermented complete feed based on sago residues significantly influenced $(P<0.05)$ on $\mathrm{pH}$, NH3, VFA total, IVDMD and IVOMD. Generally, commercial fermentation products mainly SBP produced better feed quality by improving the values of $\mathrm{pH}, \mathrm{NH} 3$, VFA total, IVDMD and IVOMD. However, types and total microorganisms were needed to be determined before experiment.

\section{Acknowledgement}

This research has been supported by grants from Syiah Kuala University under Syiah Kuala University Excellence Research (Penelitian Unggulan Universitas-PU2) in 2015. The authors thank to "Bina Usaha Farmers Group" as our partner for this experiment and to Dian Anggraeni at IPB, Ilham and M. Hanafiah at Unsyiah for their assistance and chemical analysis.

\section{References}

Alltech. 2012. Asidosis. [Terhubung berkala]. www.alltech.com/animal nutritition/beef cattle Lchallenges/beef cattle acidosis. Retrieved 05/02/2012.

Bata M. 2008. Molasses effect on hay ammonization on dry matter and organic matter digestibility in vitro. Agripet. 8(2):15-20. 
Baldwin RL. 1995. Modelling Ruminant Digestion and Metabolism. Chapman \& Hall, London.

Bisaria R, M Madan and P Vasudevan. 1997. Utilisation of agro-residues as animal feed through bioconversion. Bioresource Technology, 59(1): 5-8.

Chistiyanto M dan A Subrata. 2005. Physical and biological treatment of agricultural industry waste on fibre composition. Research Report Dikti-Undip. Semarang.

Czerkawski JW. 1986. An Introduction to Rumen Studies. Pergamon Press, Oxford.

Dawson KA and KE Newman. 1988. Fermentation in rumen-stimulating continous culture receiving probiotic supplements. J. Anim Sci. 66 (Suppl. 1):500 (Abstract).

Dutta TK, SS Kundu and DD Sharma. 2001. Potential of probiotic supplementation on in-vitro rumen fermentation and $35 \mathrm{~S}$ incorporation in microbial protein. Indian J. Anim. Nutr. 18:227-234.

Erdman RA. 1988. Dietary buffering requirement of the lactating dairy cows. A Review. J. Dairy Sci.71:3246-3266.

General Laboratory Procedures. 1966. Departement of Dairy Science. University of Wisconsin. Madison.

Hilakore MA. 2008. Improving putak nutritive through combined fermentation of Trichoderma reesei and Aspergillus niger as ruminant feed. Dissertation, raduate School IPB, Bogor.

Jean-Blain C. 1991. Rumen disfunction. Di dalam: Jouany, J.P. (Ed.). Rumen Microbial Metabolism and Ruminant Digestion. INRA, Paris. Pp. 161164.

Krause DO, RJ Bunch, LL Colan, PM Kennedy, WJ Smith, RI Mackie and CS McSweeney. 2001. Repeated dosing of ruminococcus spp. does not result in persistance, but changes in other microbial populations occur that can be measured with quantitative-165-V RNA-based probes. Microbiol. 147:1719-1729.

Linggang, SLY Phang, MH Wasoh and S Abd-Aziz. 2012. Sago Pith Residue as an Alternative Cheap Substrate for Fermentable Sugars Production. Appl Biochem Biotechnol, 167:122-131

Lin L, X Kan, H Yan, and D Wang. 2012. Characterization of extracellular cellulosedegrading enzymes from Bacillus thuringiensis strains. Electronic J. Biotech. 15(3):1-7.

Mc. Donald P, RA Edwards, JFD Greenhalgh and CA Morgan. 2002. Animal Nutrition. $6^{\text {th }}$ Ed. Sci. and Tecnol. Publ. with Jhon Willey Inc, New York.

Oeztuerk H, B Schroeder, M Beterbach and G Breves. 2005. Influence of living and autoclaved yeast of Saccharomyces boulardii on in vitro ruminal microbial metabolism. J. Dairy Sci. 88:25942600.
Pandey A, CR Socco, P Nigam, and VT Soccol. 2000. Biotechnological potential of agro-industrial residues. I: sugarcane bagasse. Bioresource Technology. Volume 74, Issue 1, August 2000, Pages 69-80.

Parakkasi A. 1999. Ilmu Nutrisi dan Makanan Ternak Ruminansia. Universitas Indonesia Press, Jakarta.

Perry TW, AE Cullison and RS Lowrey. 2003. Feeds and Feeding. $6^{\text {th }}$ Ed. Prentice Hall of Upper Saddle River, New Jersey.

Piwonka EJ, and JL Firkins. 1996. Effect of glucose fermentation on fiber digestion by ruminal microorganism in vitro. J. Dairy Sci. 79:21962206.

Rahman MM, M Lourenco, HA Hassim, JJP Boars, ASM Sonnenberg, JW Cone, J De Boever and V Fievez. 2011. Improving ruminal degradability of oil palm fronds using white rot fungi. Anim. Feed. Sci. and Tech. 169(3-4):157-166.

Russell JB, and RJ Wallace. 1997. Energy-yielding and energy-consuming reactions. Di dalam: PN Hobson and CS Stewart (Eds). The Rumen Microbial Ecosystem. $2^{\text {nd }}$ Ed. Blackie Academic \& Professional. Pp. 246-282.

Samadi. 2012. Konsep ideal protein (asam amino) fokus pada ternak ayam pedaging (review artikel). Agripet. 12(2): 42-48.

Samadi and Liebert. 2008. Modelling the optimal lysine to threonine ratio in growing chickens depending on age and efficiency of dietary amino acid utilisation. Agripet. 49(1):45-54.

Samadi and P Yu. 2011. Dry and moist heatinginduced changes in protein molecular structure, protein subfraction, and nutrient profiles in soybeans. J. Dairy Sci. 94 :6092-6102.

Samadi, K Theodoridou and P Yu. 2013. Detect the sensitivity and response of protein molecular structure of whole canola seed (yellow and brown) to different heat processing methods and relation to protein utilization and availability using ATR-FT/IR molecular spectroscopy with chemometrics. Spectrochimica Acta Part A: Molecular and Biomolecular Spectroscopy 105 :304-313.

Sangadji I. 2009. Optimizing the utilization of sago starch as ruminant feed through bioprocess with (Pleurotus ostreatus) and ammonization. Dissertation. Graduate School IPB, Bogor.

Shrivastava B, S Thakur, Y Pal Khasa, A Gupte, AK Puniya and RC Kuhad. 2011. White-rot fungal conversion of wheat straw to energy rich cattle feed. Biodegradation. 22(4):823-831.

Soejono M. 1996. Feed Analysis and Evaluation. Laboratory Direction. Animal Science Faculty UGM, Yogyakarta. 
Steel RGD and JH Torrie. 1993. Statistics Principle and Procedure. Translated by B. Sumantri. Cet. Ke-2. PT. Gramedia Pustaka Utama. Jakarta.

Suryahadi and IK Amrullah. 1989. Making "ogrea" as by product feed from cassava plant and process fermented with Aspergillus niger [Research report]. DP4M IPB, Bogor.

Syahrir S. 2009. Potential of Murbei leaves in improving hay efficiency as beef cattle feed.. Dissertation. Graduate school IPB, Bogor.

Tampoebolon BIM, 2009. Kajian perbedaan aras dan lama pemeraman fermentasi ampas sagu dengan Aspergillus niger terhadap kandungan protein kasar dan serat kasar. Seminar Nasional Kebangkitan Peternakan - Semarang.

Tang SX, GO Tayo, ZH Tan, LX Shen, CS Zhou, WJ Xiao, XF Han and SB Shen. 2008. Effects of yeast culture and fibrolytic enzyme supplementation on in vitro fermentation characteristics of lowquality cereal straws. J. Anim. Sci. 86(5):11641172.

Tilley JMA and RA Terry. 1963. A two stage technique for the in vitro digestion of forage crops. J. Br. Grass: 18: 104-112

Thalib AB. Haryanto, H Hamid, D Suherman and Mulyani. 2001. Effect of combined defaunator and probiotic on rumen ecosystem and performance of sheep. JITV 6:83-88.

Van Soest PJ. 2006. Review: rice straw, the role of silica and treatments to improve quality. Anim. Feed Sci. Technol. 130:137-171.

Viola E, F Zimbardi, M Cardinale, G Cardinale, G Braccio and E Gambacorta. 2008. Processing cereal straws by steam explosion in a pilot plant to enhance digestibility in ruminants. Bioresources Technology. 99(4):681-689.

Wajizah S, Samadi, Y Usman and E Mariana. 2015. Evaluation of Nutrient value and in vitro digestibility of palm oil fronds fermented with Aspergillus niger with different types of carbohydrate addition. Agripet. 15(1):13-19

Wanapat M, S Polyrach, K Boonnop, C Mapato and A Cherdthong. 2009. Effect of treating rice straw with urea and calcium hydroxide upon intake, digestibility, rumen fermentation and milk yield of dairy cows. Livest. Sci. 125:238-243.

Waldron MR, FN Schrick, JD Quigley, JL Klotz, AM Saxton and RN Heitmann. 2002. Volatile fatty acid metabolism by epithelial cells isolated from different areas of ewe rumen. J. Anim. Sci. 80:270-278.

Wulandari S, A Agus, M Soejono, MN Cahyanto and R Utomo. 2014. Performance of sheep fed with pod cacao-based fermented feed and nutrient digestibility in vivo. 38(1):42-50.

Widyastuti Y. 2008. Silage fermentation and the benefit of probiotic silage for ruminant.. Review. Media Peternakan. 31(3):225-232.

Wina E. 2005. Teknologi pemanfaatan mikroorganisme dalam pakan untuk meningkatkan produktivitas ternak ruminansia di Indonesia: Sebuah Review. Wartazoa. 15(4):173186.

Wiryawan KG, E Wina and R Ernawati. 1999. Utilization of kaliandra tannin (Calliandra calothyrsus) as the protection agent of protein feed (In vitro).Proceeding Seminar of research findings in science. Pusat Antar Universitas IPB, Bogor.

Wulandari S, A Agus, M Soejono and MN Cahyanto. 2014. digestibility and Biodegradation of cacao pod theobomin with fermentation using multi microbe inoculum. Agritech. 34(2):160-169.

Wulandari S, A. Agus, M Soejono, MN Cahyanto, and R. Utomo. $2014^{\mathrm{b}}$. Performance of sheep fed with pod cacao-based fermented feed and nutrient digestibility in vivo. Buletin Peternakan. 38(1):4250.

Yoon IX, and MD Stern. 1995. Influence of direct-fed micobials on ruminal fermentation and performance of ruminants. A Review. J. Anim. Sci. 8:535-555.

Zadrazil F and AK Puniya. 1995. Studies on the effect of particle size on solid-state fermentation of sugarcane bagasse into animal feed using whiterot fungi. Bioresource Technology. 54(1):85-87 